\title{
Inheritance of Leaf Rust and Stripe Rust Resistance in the Brazilian Wheat Cultivar 'Toropi'
}

Silvia B. Rosa, Agriculture and Agri-Food Canada, Morden Research Centre, Morden, MB, R6M 1Y5, Canada; and Plant Science Department, University of Manitoba, Winnipeg, MB, R3T 2N2, Canada; Brent McCallum, Agriculture and Agri-Food Canada, Morden Research Centre; Anita Brûlé-Babel, Plant Science Department, University of Manitoba, Winnipeg; Colin Hiebert, Agriculture and Agri-Food Canada, Morden Research Centre; Stephen Shorter, Plant and Food Research, Canterbury Agriculture \& Science Centre, Lincoln, New Zealand; Harpinder S. Randhawa, Agriculture and Agri-Food Canada, Lethbridge Research Centre, Lethbridge, Alberta, Canada; and Amarilis L. Barcellos, OR Melhoramento de Sementes Ltda., Passo Fundo, 99050-380, Brazil

\begin{abstract}
Rosa, S. B. McCallum, B., Brûlé-Babel, A., Hiebert, C., Shorter, S., Randhawa, H. S., and Barcellos, A. L. 2016. Inheritance of leaf rust and stripe rust resistance in the Brazilian wheat cultivar 'Toropi'. Plant Dis. 100:1132-1137.

Leaf rust (Puccinia triticina) and stripe rust (P. striiformis f. tritici) affect wheat production worldwide. Brazilian 'Toropi' wheat has demonstrated durable leaf rust resistance in South America since its release in 1965. It was previously found to have up to two adult plant leaf rust resistance genes. The leaf and stripe rust resistance of Toropi were studied by analyzing a doubled-haploid population made by crossing with susceptible 'Thatcher'. Toropi expressed good resistance to leaf rust in Canada,

Brazil, and New Zealand. Based on field and greenhouse testing, the leaf rust resistance of Toropi is conferred by two race-nonspecific complementary adult plant genes and a race-specific adult plant gene. The stripe rust resistance of Toropi analyzed in New Zealand and in Canada is based on up to two resistance genes. Toropi should provide an important contribution to rust resistance because it expressed good leaf rust and stripe rust resistance in different parts of the world.
\end{abstract}

Wheat rusts have been threatening the sustainable production of wheat for thousands of years and are still responsible for frequent yield losses in wheat. There are three rust diseases: leaf rust (Puccinia triticina Erikss.), stem rust (P. graminis f. tritici Erikss. \& Henning), and stripe rust ( $P$. striiformis f. tritici Erikss.). They differ in morphology and optimal environmental conditions for growth. Leaf rust is the most common and widespread rust of wheat worldwide, stripe rust is an important disease where wheat is grown in cooler temperatures and has been increasing in prevalence even in warmer conditions, and stem rust is considered to be the most destructive disease among the rusts. All three rusts occur worldwide; however, their incidence is dependent on climate, the pathogen population, and the degree of resistance of the predominant cultivars (Knott 1989; Kolmer et al. 2009).

To date, more than 70 leaf rust $(L r)$ and 60 stripe rust $(Y r)$ resistance genes have been named (McIntosh et al. 2013); however, breeders worldwide rely on relatively few genes in their programs. Many leaf and stripe rust genes are from wild species. Linkage drag from introgression of large chromosomal regions from wild species can lead to incorporation of undesirable traits associated with the resistance genes. Some genes have lost their effectiveness due to evolving Puccinia races. On average, a cultivar with race-specific $\mathrm{Yr}$ genes retains effective resistance for 3.5 years (Chen 2005). Combinations of genes are used to increase the effective longevity of resistance genes. Molecular markers linked to the genes are important in facilitating the incorporation of multiple resistance genes into a cultivar. The use of resistance genes in wheat cultivars is affected by many factors, including the effectiveness of the gene, availability of tightly linked or gene-specific molecular markers, presence of linked deleterious genes, incorporation into elite germplasm, and durability of the effectiveness of the gene over time in production. The combination of four to five minor genes with partial resistance

Corresponding author: S. B. Rosa; E-mail: silvia@orsementes.com.br

Accepted for publication 14 December 2015.

http://dx.doi.org/10.1094/PDIS-10-15-1128-RE

(C) 2016 The American Phytopathological Society can result in durable, highly resistant wheat cultivars (Singh et al. 2011). Adult plant resistance (APR) genes, particularly the genes conferring partial resistance in a race-nonspecific manner to one or multiple rust diseases, should be deployed in combination with other genes as the basis of rust resistance in wheat cultivars (Lagudah 2011). Three genes (Lr34/Yr18/Sr57, Lr46/Yr29, and Lr67/Yr46/Sr55) have been described as conferring slow-rusting, race-nonspecific APR to multiple rust diseases (Herrera-Foessel et al. 2011; Hiebert et al. 2010; Krattinger et al. 2009; Rosewarne et al. 2006; William et al. 2003; William et al. 2006). Lr68 was also described conferring partial resistance to leaf rust (Herrera-Foessel et al. 2012).

'Toropi' (Frontana 1971.37/Quaderna A//Petiblanco 8) is a Brazilian wheat cultivar released in 1965 , which was widely cultivated for over 15 years, while maintaining its leaf rust resistance for more than 40 years. Leaf rust resistance in Toropi is conferred by a combination of resistance genes (Barcellos et al. 2000; Liu and Kolmer 1998). Barcellos et al. (2000) identified the presence of two recessive APR genes in Toropi (tentatively named $L r T r p-1$ and $L r T r p-2$ genes) under greenhouse conditions and in the field in Mexico, but only one gene was effective under field conditions in Brazil. The two leaf rust Toropi genes were mapped on chromosome 1A and 4DS (Da-Silva et al. 2012). Prehaustorial resistance was responsible for this leaf rust resistance (Wesp-Guterres et al. 2013), and the transcriptions of genes involved with plant lignification, oxidative stress, regulation of energy supply, water and lipid transport, and cell cycle regulation were altered over $72 \mathrm{~h}$ after $P$. triticina inoculation (Casassola et al 2015). Studies on the stripe rust resistance in Toropi have not been reported.

The objective of the present study was to determine the inheritance of leaf rust and stripe rust resistance in Toropi using greenhouse data and field screening in Canada, Brazil, and New Zealand.

\section{Materials and Methods}

Inheritance of Toropi leaf and stripe rust resistance. A selection of Toropi (Toropi-6), previously made by Barcellos et al. (2000), was used throughout this study. A second source of Toropi, which originated from seed increases in Uruguay (Toropi-Ur), was also tested (kindly provided by Dr. Silvia German, INIA, Uruguay). 
In the greenhouse, Toropi-6 and 'Thatcher' were inoculated with $P$. triticina at the seedling and adult stages following the procedures described by McCallum and Seto-Goh (2003) with six Canadian $P$. triticina races: BBBD, MBDS, MGBJ, TDBG, and TJBJ. The race nomenclature followed the North American nomenclature (Long and Kolmer 1989).

Toropi-6 was heterogeneous for resistance to the highly avirulent leaf rust race BBBD at the seedling stage; therefore, a line that was susceptible at the seedling stage to this race was selected and named Toropi-6.4. The reason for choosing a susceptible line at seedling stage was to reduce the interference with the APR analyses, which was the objective of this study. Toropi-Ur was uniformly susceptible to BBBD, CCDS, FBDJ, KBBJ, MBDS, MBRJ, MDNS, MGBJ, TBBG, TDBG, TJBJ, and TPBG races at the seedling stage. Therefore, Toropi-6.4, with the same seedling reaction as Toropi-Ur, was selected as more representative of Toropi and was used in the subsequent experiments. Toropi- 6.4 was crossed with Thatcher to develop a doubled-haploid (DH) population from the Thatcher/ Toropi-6.4 $\mathrm{F}_{1}$ plants. Three $\mathrm{F}_{1}$ plants (Thatcher/Toropi-6.4*A, Thatcher/Toropi-6.4*B, and Thatcher/Toropi-6.4*C) were used to generate the DH population, which was composed of $246 \mathrm{DH}$ lines. The wheat/maize hybridization and embryo rescue methods were used to create the DH population (Thomas et al. 2010). Seventytwo DH lines were excluded from the analysis because of late maturity.

P. triticina races BBBD and TJBJ were used to inoculate the DH population. Three experiments were performed using BBBD to inoculate the plants at the seedling stage. The experiments differed in the adult plant inoculation method. In the first experiment, BBBD was inoculated onto one plant of each line and TJBJ was inoculated onto a second plant of each line. In the second experiment, one tiller of each plant was inoculated with BBBD while the rest of the tillers were separately inoculated with TJBJ (Rosa et al. 2014). The inoculations were done sequentially, keeping tillers inoculated with different races isolated from each other so that the effects of each race could be observed on the same plant without confounding effects. In the third experiment, the lines were only inoculated with BBBD at the adult plant stage.

In the greenhouse, the leaf rust reactions were classified according to Long and Kolmer (1989), using a 0 to 4 scale. Resistant infection types (IT) were considered ";" (hypersensitive flecks), "1" (small uredinia with necrosis), and "2" (small to medium uredinia with chlorosis). Plants with IT " 3 " (medium uredinia without chlorosis or necrosis) and "4" (large uredinia without chlorosis or necrosis) were considered susceptible (McCallum and Seto-Goh 2003). An additional class, designated " $\mathrm{X}$ " for a mesothetic reaction, was also considered resistant (Knott 1989).

Field experiments for leaf rust using the DH population were performed in Canada, New Zealand, and Brazil. In Canada, nurseries were located at different sites in Manitoba: Glenlea in 2010 (nonirrigated), Portage La Prairie in 2012 (irrigated), and Morden in 2015 (irrigated). Canadian nurseries were artificially inoculated with a mixture of $P$. triticina isolates. In New Zealand (Lincoln, Canterbury), the DH populations were tested in the 2010 and 2011 field seasons under natural infection. In Brazil, artificial inoculation with a mixture of local races was used to test the DH population at Ventania (Parana) in 2011. The DH population was also scored for stripe rust reaction in New Zealand during the 2011 field season under natural infection, and at Lethbridge, Alberta, Canada in 2013 under artificial inoculation of a mixture of local races. Thatcher and Toropi- 6 were included as checks in all locations. A randomized complete block design with two replicates was used in each field location, and the average of the replicates was considered. The nurseries were organized in small rows of $60 \mathrm{~cm}$ in Canada and $1 \mathrm{~m}$ in New Zealand, and in hills in Brazil. Spreader rows of susceptible lines were used to increase and spread the inoculum. In Manitoba (Glenlea, Portage La Prairie, and Morden) and Alberta (Lethbridge), Canada and in Brazil, spreader rows were added at regular intervals of five lines. 'Morocco' was used as the spreader in Brazil. In Canada, the spreader rows for leaf rust were composed of a mixture of leaf-rust-susceptible
Morocco, Little Club, and Thatcher. Spreaders for stripe rust in Lethbridge included a mixture of susceptible lines Morocco, SWS18, AC Barrie, and Zak. The spreader rows were inoculated by spraying urediospores mixed with light mineral oil (Bayol in Canada and Soltrol in Brazil) on leaves at early tillering to initiate the leaf rust epidemic. For stripe rust (Alberta), the same spraying with a mixture of races was applied at the late tillering stage. In New Zealand, the entire nursery area was surrounded by the striperust-susceptible Tiretea but there were no rust spreaders in a 50-m distance. In field trials, rust severity of adult plants was rated at anthesis based on the modified Cobb scale (Peterson et al. 1948) and IT $(\mathrm{R}=$ resistant, $\mathrm{MR}=$ moderately resistant, $\mathrm{MS}=$ moderately susceptible, and $\mathrm{S}=$ susceptible) of the disease on the leaf (Knott 1989; McIntosh et al. 1995).

To evaluate the goodness-of-fit of observed and expected segregation ratios of the DH population grown in the greenhouse and in the field, $\chi^{2}$ tests were used. To determine whether DH lines derived from different $F_{1}$ plants could be pooled and treated as a single population, $\chi^{2}$ tests for homogeneity $(P \geq 0.05)$ were performed. The threshold to classify the DH lines as $\mathrm{R}$ or $\mathrm{S}$ to leaf and stripe rust in each location was based on the levels of disease on the checks and the overall severity of the nursery on all lines. The cut-off points were thought to be natural divisions between the two classes looking at the dendrogram of lines with each level of severity. The average of IT and severity of leaf rust of the parental lines were as follows: Glenlea, Thatcher 61.8S and Toropi-6 5.3MS; Portage La Prairie, Thatcher 79S and Toropi-6 4.7MR; Morden, Thatcher 75S and Toropi-6.4 5MR; Brazil, Thatcher 86.7S and Toropi-6 2.3MR; New Zealand 2010, Thatcher 76.7 and Toropi-6 0; and New Zealand 2011, Thatcher 97.5 and Toropi-6 0 . The average of stripe rust severity and IT in New Zealand were in Thatcher $88.4 \mathrm{~S}$ and Toropi-6 33.8M; and, in Alberta, in Thatcher 75.7 and Toropi6.45 . Lines with severity lower than or equal to $45 \%$ of the flag leaf covered with pustules in New Zealand 2010 and 2011; 50\% in Glenlea 2010, Brazil 2011, and Morden 2015; or 55\% in Portage La Prairie 2012 were considered resistant to leaf rust, while lines with severity lower than or equal to $70 \%$ were considered resistant to stripe rust.

The leaf and stripe rust results have been compared in New Zealand in 2011, analyzing lines resistant to leaf rust and stripe rust $(\mathrm{R}: \mathrm{R})$, lines resistant just for leaf rust (R:S), lines resistant just for stripe rust ( $\mathrm{S}: \mathrm{R})$, and lines susceptible to both diseases $(\mathrm{S}: \mathrm{S})$. New Zealand in 2011 was chosen because both diseases were analyzed in the same location.

\section{Results}

Toropi leaf rust resistance. In the greenhouse, Toropi-6, ToropiUr, and Thatcher were inoculated at the seedling stage and at the adult stage with the six $P$. triticina races BBBD, MBDS, MGBJ, TDBG, and TJBJ. At the seedling stage, Thatcher and Toropi-Ur were uniformly susceptible but Toropi-6 was only uniformly susceptible to TJBJ while it was heterogeneous (some resistant and some susceptible plants) for the other races. From 58 Toropi- 6 plants tested at the seedling stage to BBBD, $74.1 \%$ had an IT of ; to $1,15.6 \%$ presented a mesothetic reaction, and $10.3 \%$ were susceptible. However, all Toropi-6 and Toropi-Ur plants tested were resistant to all the races at the adult plant stage, while Thatcher was susceptible. Toropi 6.4, derived from a single plant that was seedling susceptible to all races tested but resistant at the adult plant stage, was selected for further studies.

In the greenhouse at the adult stage, the segregation of the Thatcher/Toropi-6.4 DH population to race TJBJ corresponded to that expected for two complementary genes (3R:1S; $P=0.518)$ (Table 1), while the segregation to race BBBD corresponded to two complementary genes and another gene effective only to this race (5R:3S; $P=0.607)$. Some progeny lines were resistant to BBBD but susceptible to TJBJ at the adult plant stage, which indicated the presence of a race-specific APR gene.

Toropi-6 leaf rust field reaction was between 0 and $20 \mathrm{MR}$ in Canada during 2009, 2010, 2011, 2012, and 2015; from 1R to 5R in 
Brazil in 2011; and 0 in New Zealand during 2010 and 2011. Few MS and MR pustules distributed throughout the flag leaf characterized the leaf rust phenotypic reaction of Toropi- 6 in the greenhouse and in the field.

The Thatcher/Toropi-6.4 DH population segregated for two complementary genes (1R:3S) in Glenlea (2010), Portage La Prairie (2012), Morden (2015), and Brazil (2011) (Table 2) and for two complementary genes plus one noncomplementary gene (5R:3S) in both years in New Zealand. Any DH lines in Canada presented a low leaf rust severity like Toropi whereas, in Brazil and New Zealand in 2010 and $2011,7.1,9$, and $8.4 \%$, respectively, had low leaf rust severity comparable with Toropi (Fig. 1).

Toropi stripe rust resistance. The inheritance of stripe rust resistance of Toropi-6.4 at the adult stage was analyzed in New Zealand during the 2011 season. Thatcher expressed an average IT of $88.4 \mathrm{~S}$ to stripe rust, while Toropi- 6 presented an average IT of 33.8 MRMS. In all, $24.3 \%$ of the DH lines had less stripe rust severity than the average of Toropi-6 (Fig. 2). The segregation of the DH population best fit one gene (1R:1S; $P=0.459$; Table 3 ). The hypotheses of two independent genes and two complementary genes were also analyzed but the probability, in both cases, was less than 0.05. Comparing the stripe rust and leaf rust reactions in the DH lines, it was observed that $46.7 \%$ of the lines were resistant only to leaf rust and $10.5 \%$ only to stripe rust. The number of lines with both leaf and stripe resistance was $16.4 \%$.

The Thatcher/Toropi-6.4 DH population was also evaluated in Alberta, Canada in 2013 for stripe rust reaction. Thatcher ranged from 70 to $85 \%$ stripe rust flag leaf coverage while Toropi-6.4 showed only $5 \%$ severity. The $\chi^{2}$ test of the Thatcher/Toropi-6.4 DH population indicated the presence of two genes (3R:1S; $P=0.732$ ) for stripe rust resistance. The hypotheses of one gene and two complementary genes were tested but the probability was less than 0.05 in both situations. In total, $4.2 \%$ of the $\mathrm{DH}$ lines presented severity similar to Toropi-6.4 but lines with less severity than Toropi were not observed in Alberta (Fig. 2).

\section{Discussion}

This study demonstrated the complex nature of leaf rust resistance in Brazilian Toropi wheat. The inheritance of leaf rust and stripe rust resistance was analyzed in the Thatcher/Toropi-6.4 DH population

Table 1. Segregation ratios of Thatcher/Toropi-6.4 doubled-haploid population to race BBBD and TJBJ of Puccinia triticina at the adult plant stage in greenhouse tests at Winnipeg, Canada ${ }^{\mathrm{a}}$

\begin{tabular}{|c|c|c|c|c|c|c|c|}
\hline \multirow[b]{2}{*}{ Race } & \multirow[b]{2}{*}{ Number of genes } & \multicolumn{2}{|c|}{$\begin{array}{c}\text { Number } \\
\text { of lines }\end{array}$} & \multicolumn{2}{|c|}{$\begin{array}{c}\text { Expected } \\
\text { ratio }\end{array}$} & \multirow[b]{2}{*}{$x^{2}$} & \multirow[b]{2}{*}{ Probability } \\
\hline & & $\mathbf{R}$ & $\mathbf{S}$ & $\mathbf{R}$ & $\mathbf{S}$ & & \\
\hline$\overline{\mathrm{BBBD}}$ & 2 complementary +1 & 73 & 49 & 5 & 3 & 0.26 & 0.607 \\
\hline TJBJ & 2 complementary & 43 & 113 & 1 & 3 & 0.42 & 0.518 \\
\hline
\end{tabular}

a Three and two experiments were conducted with BBBD and TJBJ, respectively. The average of the experiments is presented. $R=$ resistance and $\mathrm{S}=$ susceptible. in the greenhouse and the field in Canada, Brazil, and New Zealand. For leaf rust resistance, Toropi-6.4 has three APR genes, two racenonspecific complementary genes, and one race-specific gene. The two complementary genes were effective in all field locations and the greenhouse, whereas the APR race-specific gene conferred resistance only in New Zealand and in the greenhouse to the avirulent race BBBD. The stripe rust resistance of Toropi is conferred by up to two genes.

In this study, all $\mathrm{F}_{1}$ plants, from the Thatcher/Toropi-6.4 $\mathrm{DH}$ population were susceptible to $P$. triticina race TJBJ at the adult plant stage, while $27.6 \%$ of DH lines derived from these $\mathrm{F}_{1}$ plants were resistant to the same race, confirming that the genes were recessive. Two genes were effective in all locations tested to date across Canada, Brazil, and New Zealand, supporting the idea that these two genes may have effectiveness in controlling leaf rust in different regions of the world. Barcellos et al. (2000) also found that leaf rust resistance in Toropi was controlled by two recessive complementary APR genes (LrTrp-1 and LrTrp-2) in greenhouse studies but acted independently to field condition in Mexico. During our observations, the genes acted in a complementary manner in all locations. The complementary nature of the leaf rust resistance genes could be modified by the environment or by the pathogen (Rosewarne et al. 2008), explaining the different results obtained from Barcellos et al. (2000). The $\chi^{2}$ tests assumed that all genes contribute equally to the resistance; however, that is not necessarily the case when minor genes are involved. A $\chi^{2}$ analysis was not able to identify some minor quantitative trait loci presented in an Avocet/Pastor population tested for leaf and stripe rust resistance in a multienvironment analysis (Rosewarne et al. 2012). The expression of some leaf rust genes could be modified according to the temperature. For example, Lr34 is less effective in high-temperature conditions, whereas the resistance of $L r 13$ becomes more effective in the same conditions (McIntosh et al. 1995).

When analyzing the leaf rust reaction of Toropi and the DH lines in the greenhouse, we found a race-specific APR gene which showed resistance to BBBD but susceptibility to TJBJ. The phenotype of this gene was characterized by a mixture of susceptible and resistant pustules $(3$; reaction), similar to a minor gene (HerreraFoessel et al. 2011, 2012; Hiebert et al. 2010; McIntosh et al. 1995). This gene conditioned an intermediate level of resistance in both seasons in New Zealand but was not effective in Canada or Brazil.

Toropi-6 also has effective resistance against stripe rust. The $\chi^{2}$ tests indicated the presence of up to two genes conferring stripe rust resistance. The possibility that the same genes could condition both leaf and stripe rust was investigated but the correlation was too low. The leaf and stripe rust results have been compared in New Zealand in 2011, where the $\chi^{2}$ test indicated the presence of two complementary plus one gene for leaf rust resistance and one gene for stripe rust resistance. It was clear that there were genes conferring only leaf rust (R:S, 46.7\%) and only stripe rust (S:R, 10.5\%). The number of lines with both leaf and stripe resistance was $16.4 \%$. A common $Y r$ gene should be effective in New Zealand and in Canada, because only $4 \%$ of a total of 141 lines showed resistance in New Zealand but

Table 2. Segregation for leaf rust resistance of Thatcher/Toropi-6.4 doubled-haploid population in field experiments at New Zealand under natural infection and in Brazil and Canada under artificial inoculations with a mixture of races ${ }^{\mathrm{a}}$

\begin{tabular}{|c|c|c|c|c|c|c|c|}
\hline \multirow[b]{2}{*}{ Location, year } & \multirow[b]{2}{*}{ Genes $^{\mathbf{b}}$} & \multicolumn{2}{|c|}{ Number of lines } & \multicolumn{2}{|c|}{ Expected ratio } & \multirow[b]{2}{*}{$\chi^{2}$} & \multirow[b]{2}{*}{ Probability } \\
\hline & & $\mathbf{R}$ & $\mathbf{S}$ & $\mathbf{R}$ & $\mathbf{S}$ & & \\
\hline \multicolumn{8}{|l|}{$\overline{\text { Canada }}$} \\
\hline Glenlea 2010 & 2 Comp & 34 & 138 & 1 & 3 & 2.24 & 0.134 \\
\hline Portage La Prairie 2012 & 2 Comp & 41 & 130 & 1 & 3 & 0.05 & 0.825 \\
\hline Morden 2015 & 2 Comp & 41 & 139 & 1 & 3 & 0.6 & 0.44 \\
\hline Brazil 2011 & 2 Comp & 23 & 61 & 1 & 3 & 0.14 & 0.705 \\
\hline New Zealand 2010 & 2 Comp +1 & 89 & 43 & 5 & 3 & 1.16 & 0.281 \\
\hline New Zealand 2011 & 2 Comp +1 & 73 & 34 & 5 & 3 & 1.26 & 0.261 \\
\hline
\end{tabular}

${ }^{a}$ Results are based on the average of two replicates. $\mathrm{R}=$ resistance and $\mathrm{S}=$ susceptible.

${ }^{b}$ Number of genes. Comp $=$ complementary. 
susceptibility in Canada, and $19 \%$ were resistant in Alberta but not in New Zealand. The difference between the results between locations could be explained by an additional gene that was effective in Alberta but not in New Zealand. Transgressive segregation was observed with lines with less stripe rust severity than Toropi in New Zealand but not in Alberta. If Thatcher has stripe rust resistance genes, they were not effective in New Zealand and Alberta, where the average

Glenlea 2010
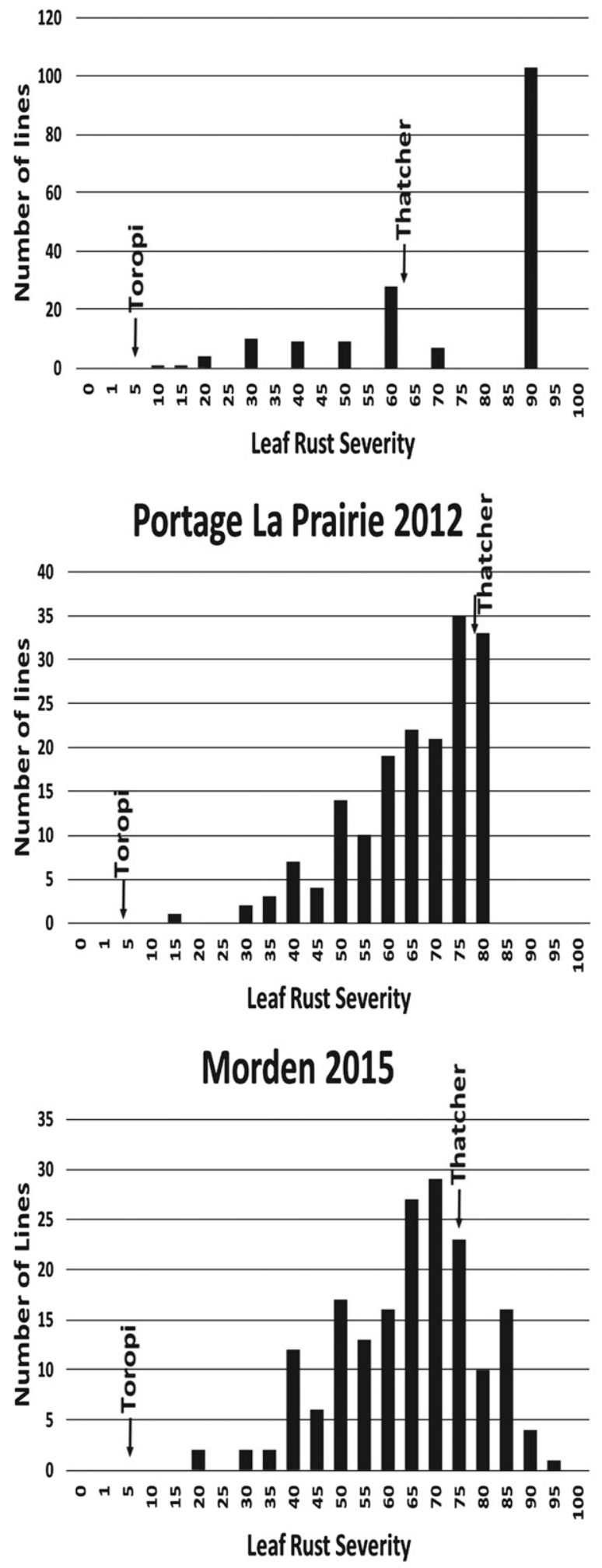

Fig 1. Leaf rust severity of the Thatcher/Toropi-6.4 population in different locations. of stripe rust severity was 88.5 and $75.7 \%$, respectively. The transgressive segregation could be explained by an additive effect of the Toropi and Thatcher genes, comparable with the effect of $L r 13$ and Lr34 used in combination (German and Kolmer 1992). Lr13 is not effective in many regions of the world but, in combination with Lr34, it enhances the resistance conferred by Lr34. Transgressive segregation on leaf rust resistance was not observed.

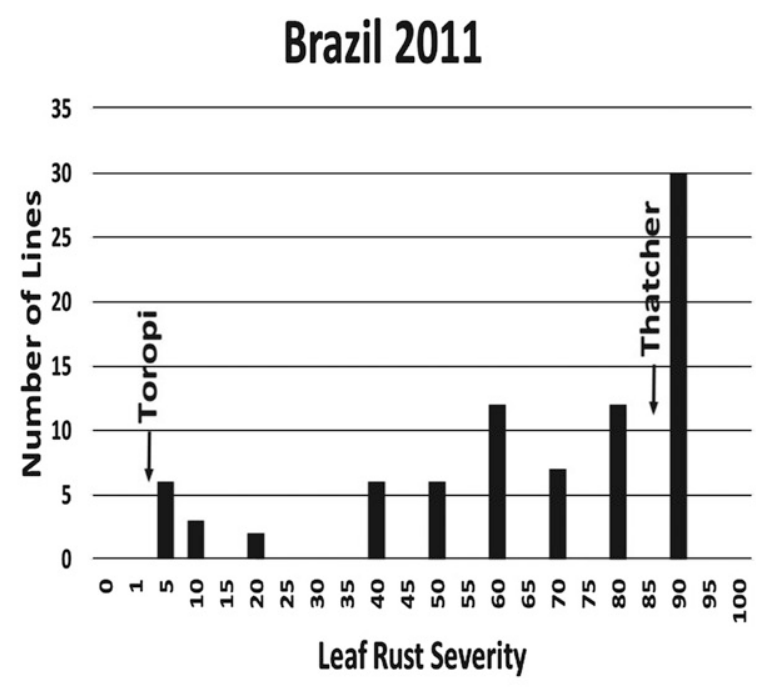

New Zealand 2010

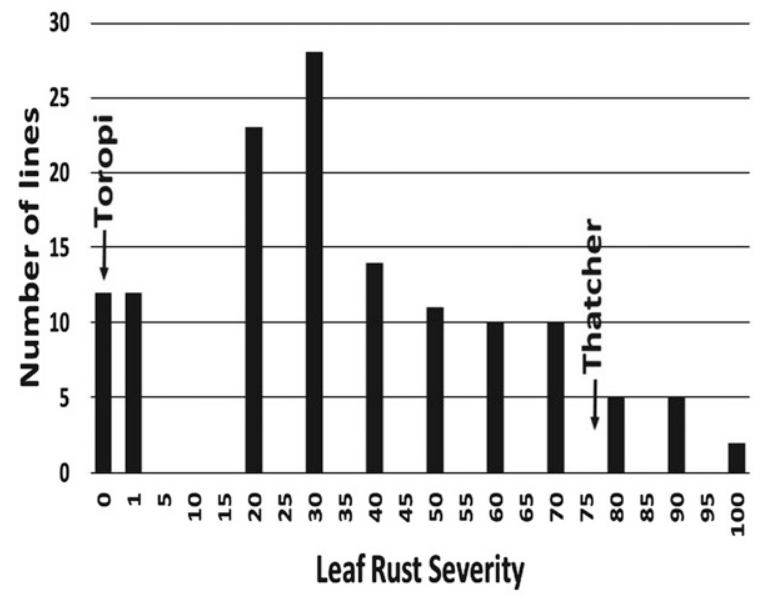

New Zealand 2011

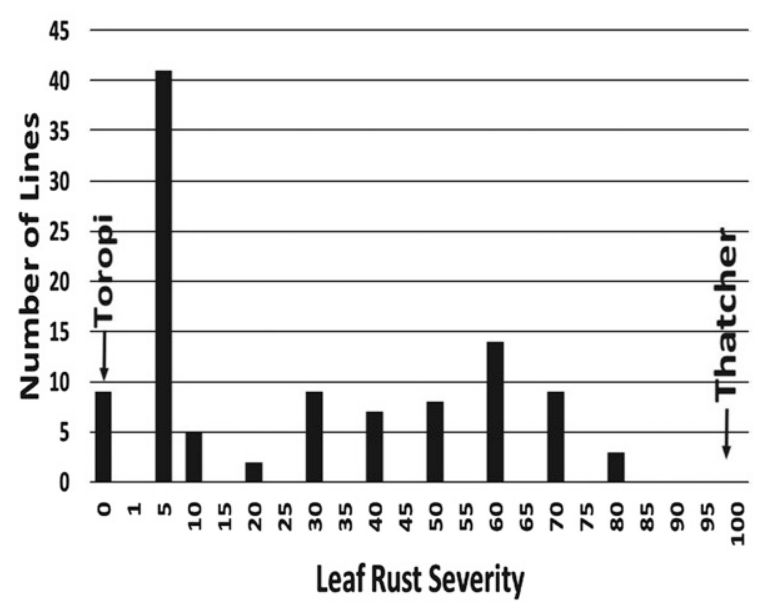


The two APR genes LrTrp-1 and LrTrp-2, previously described in Toropi by Barcellos et al. (2000) and Da-Silva et al. (2012), are likely the same genes identified in the present study. These two genes conditioned a high level of resistance to leaf rust in Canada, New Zealand, and Brazil over a number of years, which indicates their possible race-nonspecific nature. The future aim is to locate and map the rust resistance genes in Toropi. To date, Toropi demonstrated a high level of durable leaf rust resistance in South America and high

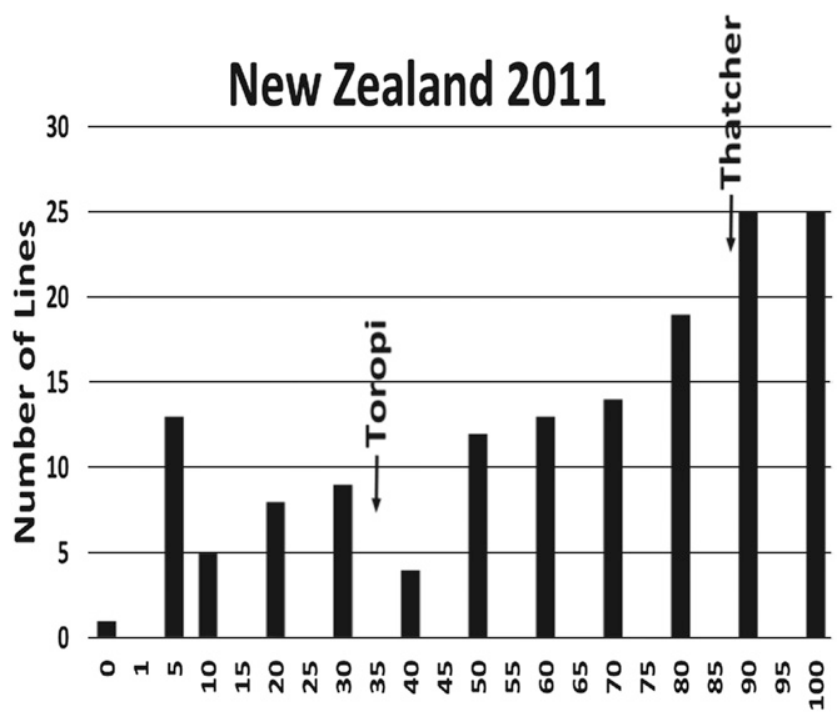

Stripe Rust Severity

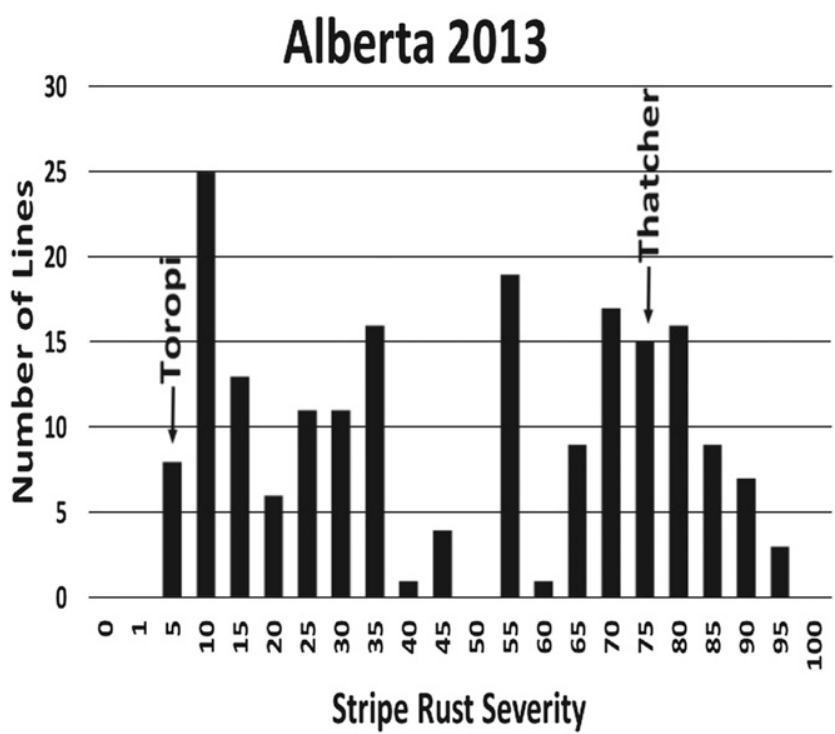

Fig 2. Stripe rust severity of the Thatcher/Toropi-6.4 population in different locations.

Table 3. Segregation for stripe rust resistance of Thatcher/Toropi-6.4 doubled-haploid population in the field in New Zealand in 2011 under natural infection and in Alberta - Canada in 2013, under a mixture of races ${ }^{\mathrm{a}}$

\begin{tabular}{|c|c|c|c|c|c|c|c|}
\hline \multirow[b]{2}{*}{ Location, year } & \multirow[b]{2}{*}{ Genes $^{b}$} & \multicolumn{2}{|c|}{$\begin{array}{c}\text { Number } \\
\text { of lines }\end{array}$} & \multicolumn{2}{|c|}{$\begin{array}{l}\text { Expected } \\
\text { ratio }\end{array}$} & \multirow[b]{2}{*}{$\chi^{2}$} & \multirow[b]{2}{*}{ Probability } \\
\hline & & $\mathbf{R}$ & $\bar{S}$ & $\mathbf{R}$ & $\bar{S}$ & & \\
\hline $\begin{array}{l}\text { New Zealand, } \\
2011\end{array}$ & 1 & 79 & 69 & 1 & 1 & 0.55 & 0.459 \\
\hline Alberta, 2013 & 2 Noncomp & 141 & 50 & 3 & 1 & 0.12 & 0.732 \\
\hline
\end{tabular}

${ }^{a}$ Results were based on the average of two replicates. $\mathrm{R}=$ resistance and $\mathrm{S}=$ susceptible.

b Number of genes. Noncomp $=$ noncomplementary. levels of leaf and stripe rust resistance in North America and in New Zealand, indicating that it is a good source of rust resistance to both diseases.

\section{Acknowledgments}

We thank P. Seto-Goh and other members of the Wheat Leaf Rust lab and DH and Breeding Lab of Cereal Research Centre - Agriculture and Agri-Food Canada for their technical support; and C. Turra and members of OR Melhoramento de Sementes. This project was funded by Agri-Food Research and Development Initiative, Natural Sciences and Engineering Research Council of Canada and the Willy Wiebe Graduate Student Scholarship.

\section{Literature Cited}

Barcellos, A. L., Roelfs, A. P., and de Moraes-Fernandes, M. I. B. 2000. Inheritance of adult plant leaf rust resistance in the Brazilian wheat cultivar Toropi. Plant Dis. 84:90-93

Casassola, A., Brammer, S. P., Chaves, M. S., Martinelli, J. A., Stefanato, F., and Boyd, L. A. 2015. Changes in gene expression profiles as they relate to the adult plant leaf rust resistance in the wheat cv. Toropi. Physiol. Mol. Plant Pathol. 89: 49-54.

Chen, X. M. 2005. Epidemiology and control of stripe rust Puccinia striiformis f. sp. tritici on wheat. Can. J. Plant Pathol. 27:314-337.

Da-Silva, P. R., Brammer, S. P., Guerra, D., Milach, S. C. K., Barcellos, A. L., and Baggio, M. I. 2012. Monosomic and molecular mapping of adult plant leaf rust resistance genes in the Brazilian wheat cultivar Toropi. Genet. Mol. Res. 11: 2823-2834.

German, S. E., and Kolmer, J. A. 1992. Effect of gene Lr34 in the enhancement of resistance to leaf rust of wheat. Theor. Appl. Genet. 84:97-105.

Herrera-Foessel, S. A., Lagudah, E. S., Huerta-Espino, J., Hayden, M. J., Bariana, H. S., Singh, D., and Singh, R. P. 2011. New slow-rusting leaf rust and stripe rust resistance genes $\operatorname{Lr67}$ and $Y r 46$ in wheat are pleiotropic or closely linked. Theor. Appl. Genet. 122:239-249.

Herrera-Foessel, S. A., Singh, R. P., Huerta-Espino, J., Rosewarne, G. M., Periyannan, S. K., Viccars, L., Calvo-Salazar, V., Lan, C. X., and Lagudah, E. S. 2012. Lr68: A new gene conferring slow rusting resistance to leaf rust in wheat. Theor. Appl. Genet. 124:1475-1486.

Hiebert, C. W., Thomas, J. B., McCallum, B. D., Humphreys, D. G., DePauw, R. M., Hayden, M. J., Mago, R., Schnippenkoetter, W., and Spielmeyer, W. 2010. An introgression on wheat chromosome 4DL in RL6077 (Thatcher*6/PI 250413) confers adult plant resistance to stripe rust and leaf rust ( $\operatorname{r67}$ 67). Theor. Appl. Genet. 121:1083-1091.

Knott, D. R. 1989. The Wheat Rusts: Breeding for Resistance. Springer-Verlag, Berlin Heidelberg, Germany.

Kolmer, J., Chen, X., and Jin, Y. 2009. Diseases which challenge global wheat production - the wheat rusts. Pages 89-124 in: Wheat: Science and Trade. B. F. Carver, ed. Wiley-Blackwell, Ames, IA.

Krattinger, S. G., Lagudah, E. S., Spielmeyer, W., Singh, R. P., Huerta-Espino, J., McFadden, H., Bossolini, E., Selter, L. L., and Keller, B. 2009. A putative ABC transporter confers durable resistance to multiple fungal pathogens in wheat. Science 323:1360-1363.

Lagudah, E. S. 2011. Molecular genetics of race non-specific rust resistance in wheat. Euphytica 179:81-91.

Liu, J. Q., and Kolmer, J. A. 1998. Inheritance of leaf rust resistance in four wheat landraces and cultivars. Can. J. Plant Pathol. 20:125.

Long, D. L., and Kolmer, J. A. 1989. A North American system of nomenclature for Puccinia recondita f. sp. tritici. Phytopathology 79:525-529.

McCallum, B. D., and Seto-Goh, P. 2003. Physiologic specialization of wheat leaf rust Puccinia triticina in Canada in 2000. Can. J. Plant Pathol. 25:91-97.

McIntosh, R. A., Dubcovsky, J., Rogers, W. J., Morris, C., Appels, R. X. C., and Xia, X. C. 2013. Catalogue of gene symbols for wheat: 2013-2014 Supplement. Online publication. http://www.shigen.nig.ac.jp/wheat/komugi/genes/macgene/ supplement2013.pdf

McIntosh, R. A., Wellings, C. R., and Park, R. F. 1995. Wheat Rust: An Atlas of Resistance Genes. CSIRO, East Melbourne, Australia.

Peterson, R. F., Campbell, A. B., and Hannah, A. E. 1948. A diagrammatic scale for estimating rust intensity on leaves and stems of cereals. Can. J. Res. 26c: 496-500.

Rosa, S. B., McCallum, B. D., Seto-Goh, P., and Brule-Babel, A. 2014. Double artificial inoculation of Puccinia triticina in the study of wheat leaf rust resistance. Can. J. Plant Pathol. 36:83-88.

Rosewarne, G. M., Singh, R. P., Huerta-Espino, J., Herrera-Foessel, S. A., Forrest, K. L., Hayden, M. J., and Rebetzke, G. J. 2012. Analysis of leaf and stripe rust severities reveals pathotype changes and multiple minor QTLs associated with resistance in an Avocet x Pastor wheat population. Theor. Appl. Genet. 124: 1283-1294.

Rosewarne, G. M., Singh, R. P., Huerta-Espino, J., and Rebetzke, G. J. 2008. Quantitative trait loci for slow-rusting resistance in wheat to leaf rust and stripe rust identified with multi-environment analysis. Theor. Appl. Genet. 116: 1027-1034

Rosewarne, G. M., Singh, R. P., Huerta-Espino, J., William, H. M., Bouchet, S., Cloutier, S., Mcfadden, H., and Lagudah, E. S. 2006. Leaf tip necrosis, 
molecular markers and $\beta 1$-proteasome subunits associated with the slow rusting resistance genes Lr46/Yr29. Theor. Appl. Genet. 112:500-508.

Singh, R. P., Huerta-Espino, J., Bhavani, S., Herrera-Foessel, S. A., Singh, D., Singh, P. K., Velu, G., Mason, R. E., Jin, Y., Njau, P., and Crossa, J. 2011. Race non-specific resistance to rust diseases in CIMMYT spring wheats. Euphytica 179:175-186.

Thomas, J., Nilmalgoda, S., Hiebert, C., McCallum, B., Humphreys, G., and DePauw, R. 2010. Genetic markers and leaf rust resistance of the wheat gene Lr32. Crop Sci. 50:2310-2317.
Wesp-Guterres, C., Martinelli, J. A., Graichen, F. A. S., and Chaves, M. S. 2013. Histopathology of durable adult plant resistance to leaf rust in the Brazilian wheat variety Toropi. Eur. J. Plant Pathol. 137:181-196.

William, H. M., Singh, R. P., Huerta-Espino, J., Palacios, G., and Suenaga, K. 2006. Characterization of genetic loci conferring adult plant resistance to leaf rust and stripe rust in spring wheat. Genome 49:977-990.

William, M., Singh, R. P., Huerta-Espino, J., Islas, S. O., and Hoisington, D. 2003. Molecular marker mapping of leaf rust resistance gene $L r 46$ and its association with stripe rust resistance gene $Y r 29$ in wheat. Phytopathology 93:153-159. 